DOI https://doi.org/10.36059/978-966-397-204-6/2-14

\title{
DOMESTIC EDUCATION GLOCALIZATION IN THE CULTURE AND ARTS INDUSTRY IN THE CONTEXT OF WORLD SOCIO-CULTURAL TRENDS OF THE XXI CENTURY
}

\section{Mykhailo Poplavskyi}

\section{INTRODUCTION}

Traditional culture of the Ukrainian people in particular, as well as the cultural diversity of human civilization in general, at the present stage is influenced by a complex process, leading trend which is to promote models of Western mass culture. This is a consequence of globalization processes, which, according to researchers, give rise to uniform structures in the economy and politics of different countries, as well as contribute to the adaptation of modern Western culture elements to local conditions and local traditions and it is the so-called "globalization". These processes, which over the last decades have embraced all branches of social life (political, economic, spiritual, social, etc.), have become extremely specific in the context of sociocultural processes, including education in the field of culture and art.

Education in the field of culture and art in the context of globalization is positioned as a counteraction to the phenomena of mass art, a kind of spiritual practice of social being of modern man, saturated with humanistic ideals, which opposes the nullities of postmodern culture. The innovative concept of Ukraine's development aims at an organic combination of economic and social well-being with the education development and preservation of traditional culture in line with the world's leading trends. This actualizes the study of the Ukrainian education problems in the field of culture and art as a priority issue of the state cultural policy.

\section{Impact features of the globalization processes on education}

In recent decades, debates about the cultural implications of modern globalization have prompted the need for a careful study of the societal activity impact on the so-called periphery. Predictions about the inevitability of the homogeneous Western culture formation of the Western model due to

\footnotetext{
${ }^{1}$ Rozenberg, N.V. (2014). Nacional'nye kul'tury kak vyzov globalizacii. News of higher educational institutions. Volga region. Humanitarian sciences, 3 (31), 111-117.
} 
the global distribution of certain goods, customs and traits have now shifted to the concept that globalization in certain relationships does lead to homogenization, but does not deny local identification. The main characteristic of cultural globalization, according to the foreign researchers belief ( $\mathrm{Z}$. Bauman and others) ${ }^{2}$, is a continuous process of synthesizing the global and the local that is a process of glocalization in which the intangible and material attributes coming from outside are rethought and combined to form new syntheses. At the present stage, globalization processes are significantly accelerating and expanding, integrating into all sectors of society. At the same time, localization processes are developing at a faster pace and strengthening the local dimension in the economic, social and cultural spheres. In order to focus on the presence of these two apparently opposite trends, which allow a person to move smoothly from global to local dimensions, and vice versa, the term "glocalization" was introduced by foreign researchers.

According to modern dictionaries and reference books, the term "glocal" formed due to "global and local sublimation" and it is modeled on the Japanese word "dochakuka" (literal translation is the global union within local) that primarily meant the process of adapting technology to agriculture local conditions. In the scientific dimension, the term "global" was integrated by the researcher R. Robertson in the 1980's to define global localization. According to its interdisciplinary nature, it is defined as "the creation of products and services intended for the global market but adapted to local cultures"3. In turn, German researcher J. Blatter positions "glocalization" as "the simultaneous emergence of universalizing and specifying tendencies in modern social, political and economic systems", emphasizing that glocalization indicates that the increasing importance of the continental and global is growing in parallel with local and regional levels.

The term "globality" is the link and relationship between global and local elements, social aspects, and related issues (in particular, in terms of social justice, the global concept implies the provision of global knowledge according to the local context). The term is gaining widespread popularity in the late 1980s, and at the same time, in anthropology, the social sciences, and related fields, the same term is "indigenization" has spread, which has provoked a lengthy scientific debate. "Indigenization" is defined as "a form of

${ }^{2}$ Bauman, Z. (1998). On Glocalisation: Or Globalisation for Some, Localisation for Others. Thesis Eleven, 54, 37-49.

3 Robertson, R. (1995). Glocalization: Time-Space and Homogeneity-Heterogeneity. In M. Featherstone, S. Lash and R. Robertson (eds.) Global Modernities. London/Thousand Oaks/New Delhi, Sage, p. 28. 
cultural change in which traditional communities integrate elements of another into traditional culture" (a reverse process aimed at reviving traditional cultural elements in a new form is called "indigenization") ${ }^{4}$. In the context of the world political and socio-cultural processes, indigenization is defined as the desire of many countries and cultures, which in the past, through the impulse to modernize, have borrowed Western values and ideals, to return to their own cultural traditions and values. The same opinion is shared by the Ukrainian researcher I. Dotsyak, who believes that indigenization as a process of returning to "specific roots" is one of the ways of realizing the specific development of ethno-national processes caused by globalization ${ }^{5}$. Researcher on the example of ethnographic groups of Galicia proves the indisputable promotion of globalization impacts of the indigenization development in order to preserve national identity. According to I. Dotsyak, the revival of traditional culture is based on the restoration of identity $^{6}$. Thus, indigenization, as noted by German researcher B. HauserSchaublin, is often a reaction to confrontation with another culture, respectively, each process is a self-contained form of modernization that can apply to all elements of culture such as folklore, languages, customs, etc. ${ }^{7}$ Therefore, the level of demand for possible local specificity depends on the strength of globalization. Specifically, R. Robertson argues that the local and global trends "complement each other, and in some cases may lead to a clash between" ${ }^{\prime}$. Glocalization combines the modernization processes of local cultures with the achievements of a shaping global multicultural civilization.

M. Kozhevnikov and N. Pashkevich emphasize that the natural processes of development occur simultaneously in both sides of global and locality is globalization, therefore, leads to the fact that global is not a one-dimensional space, but a trans-locality, as the increasing approach of the poles of global and locality. Researchers point out that the term "globalism" is characterized by a specific strategy of combining local and global orientations and interests in politics, economy and culture, and therefore corresponds to the concept of

${ }^{4}$ Rietdorf, U. (2001). Minderheiten und ihre Bedeutung für endogene Entwicklungen in Afrika: das Beispiel Tansania. Verlag Dr. Kovač, Hamburg, p. 107.

${ }^{5}$ Dotsiak, I. (2017). Etnopolitychni protsesy na terytorii Halychyny v konteksti hlobalizatsii.

Proceedings. Institute of Political and Ethno-National Studies National Academy of Sciences of Ukraine, 1(87), p. 192.

${ }^{6}$ Ibid., p. 194.

${ }^{7}$ Hauser-Schäublin, B., Braukämper, U. (Hrsg.). (2002). Ethnologie der Globalisierung: Perspektiven kultureller Verflechtungen. D. Reimer, Berlin, p. 16.

8 Robertson, R. (1995). Glocalization: Time-Space and Homogeneity-Heterogeneity. In M. Featherstone, S. Lash and R. Robertson (eds.) Global Modernities. London/Thousand Oaks/New Delhi, Sage, p. 29-30. 
"new regionalism"9. The innovative phenomenon, unlike the old regionalism, with its protectionist orientation (introversion), implies the search for the best ways to integrate the member states of regional agreements into global processes. Therefore, globalization should not be understood as the preservation of traditional features, but their transition from the national to the global level, and most importantly the development at the regional and planetary levels.

According to the globalization concept, which implies a specific response to global processes, individual ethnos must identify their own culture and spirituality within the cross-cultural rhythmic interactions that ensure the intersection of national culture values with the spiritual orientations of the information society and the heritage of world culture masterpieces ${ }^{10}$. There is a complex network of links between economics, development and education, according to which globalization is positioned as a multifaceted phenomenon, affecting all industries, as each is important in the evolution of the other. In particular, education in the age of globalization, as A. Rolls points out, faces complex problems because, along with global migration, "new demographic realities and cultural entities are coming" ". According to M. Crossley ${ }^{12}$, these aspects (with varying degrees of variation) affect developing and developed countries.

In the latter, globalization is viewed in terms of modernizing the existing education system by improving and improvising knowledge-based exchanges of education systems in other countries. For example, by integrating the latest digital technologies into the educational process, USA or Latin American students participate in video conferencing with students in Canada or Western European countries. Thus, globalization in the education system is manifested in particular through technology, and facilitates the sharing of global knowledge. On the other hand, an important aspect of the issue is the assimilation into the educational system of developed countries of immigrants are in this case, in the process of cultural exchange, the norms of the culture of the host country, with emphasis on integration and compliance, are dominant ${ }^{13}$.

${ }^{9}$ Kozhevnikov, N.N., Pashkevich, N.L. (2005). Glokalizaciya koncepcii harakternye cherty prakticheskie aspekty. Bulletin of Yakutsk State University, 3, p. 111.

${ }^{10}$ Ibid., p. 112.

${ }^{11}$ Rolls, A. (2007). International perspectives on education. Bronx, NY: H.W. Wilson Co.

${ }^{12}$ Crossley, M. (2002). Comparative and International Education: Contemporary Challenges, Reconceptualization and New Directions for the Field. Current Issues in Comparative Education. Teachers College, Columbia University, 4(2), p. 81.

${ }^{13}$ Chinnammai, S. (2005). Effects of globalisation on education and culture. In ICDE International Conference. Madras, India: University of Madras, p. 2. 
F. Patel, exploring the specifics of the globalization of higher education, emphasizes that the paradigm of internationalization, which most educational institutions aspire to, and which certainly influences aspects of education and research, is based solely on Western systems of knowledge that underestimate and deprive opportunities of scale dissemination of other forms of knowledge. The scholar defines the internationalization of higher education as "a skillfully designed apparatus designed to generate significant profits with limited focus on context-oriented solutions or sustainable social change that impedes the development of local communities"14, and also calls for the restructuring of this concept in favor of the education glocalization, justice and inclusivity, which should contribute to the legitimacy of various forms of knowledge, respect for cultural traditions.

Glocalization seeks to combine local and universal values, putting them in a familiar context, and given the globalization complexities, which is characterized by problems in its limited outlook. Unfortunately, universal standards for global education have not yet been developed, but many scholars, institutions and organizations are offering diverse approaches:

- how educational institutions convey an understanding of the global realities, opportunities and challenges of the local context;

- how schools fulfill the mission of meeting local needs, addressing global realities and acting at the level of global aspirations ${ }^{15}$.

According to $\mathrm{H}$. Lynch and F. Patel, the glocalization of learning and teaching involves the consideration of curricula and the formation of a pedagogical link between the local and global communities in terms of social responsibility, justice and sustainability ${ }^{16}$. Researchers say that glocalization can help reduce the impact of local and global socio-economic, cultural, political and other issues through dialogue and action, while creating unique learning experiences for learning communities at the local and global levels. For example, in developed countries, such as Australia and Canada, the discourse on the globalization of higher education, focusing on life skills, employment opportunities and civil liability as desirable attributes, defines effective strategies for preparing graduates for their future role as professionals in the global environment. These attributes intersect with the

${ }^{14}$ Patel, F. (2017). Internationalization of HE Needs to be Replaced. University World News. URL: https://www.universityworldnews.com/post.php?story=20170927101224475.

15 Niemczyk, E.K. (2019). Glocal Education in Practice: Teaching, Researching, and Citizenship. In BCES Conference Books, 17. Sofia: Bulgarian Comparative Education Society, p. 14.

${ }^{16}$ Patel, F., Lynch, H. (2013). Glocalization as an Alternative to Internationalization in Higher Education: Embedding Positive Glocal Learning Perspectives. International Journal of Teaching and Learning in Higher Education, 25(2), p. 223. 
aspirations of young people to acquire intellectual and professional qualifications, as well as to acquire interpersonal skills and meet diverse needs in accordance with the trends of socio-cultural space: "Emphasis is placed on the of professionals' development who are responsive to local and global issues along with the changing needs of socio-economic trends with their typical principles of social responsibility and justice"17.

Thus, in line with H. Lynch and F. Patel's theory, globalization in the context of higher education implies a positive learning experience thanks to a respectful attitude towards cultural values. The Glocalation Dialogue aims to bring students beyond the boundaries of intercultural communication while at the same time obliging participants in the learning process to reflect on actions that demonstrate an in-depth understanding and recognition of the benefits, differences and similarities between different cultures. In this context, globalization is seen as a paradigm of empowerment.

\section{Education glocalization in the field of culture and art}

The glocalization concept of education in the field of culture and the arts is focused on the combination of global and local contexts in the teaching process. Its specific characteristic is the dominance of the conceptualization of local experience with the aim of establishing mental connections between local and global processes.

The sublimation of local and global resources in the education system, according to Austrian and German researchers, the staff of Leuphana Universität Lüneburg and the Konrad Lorenz Institute for Evolution and Cognition Research, cooperation and knowledge production. Researchers say this process overcomes social, geographical and cultural boundaries and includes a means by which learners learn about the world and take action in it $^{18}$. Accordingly, the term "global" should also be used to refer to a new sector of students "who have global aspirations, but for certain objective and subjective reasons should remain locally"19. Representatives of this sector aspire to become globally competent, but for various reasons, such as due to family circumstances, financial constraints or lack of academic performance, they cannot obtain education in leading capital institutions of higher education or abroad.

${ }^{17}$ Patel, F., Lynch, H. (2013). Glocalization as an Alternative to Internationalization in Higher Education: Embedding Positive Glocal Learning Perspectives. International Journal of Teaching and Learning in Higher Education, 25(2), p. 225.

${ }^{18}$ Caniglia, G., Bellina, L., Lang, D.J., Laubichler, M. (2017). The Glocal Curriculum: A Practical Guide to Teaching and Learning in an Interconnected World. Baden-Baden: Critical Aesthetics Publishing.

19 Niemczyk, E.K. (2019). Glocal Education in Practice: Teaching, Researching, and Citizenship. In BCES Conference Books, 17. Sofia: Bulgarian Comparative Education Society, p. 14. 
Thus, global students are choosing to benefit from a quality global education that will further their desired employment and career development at the local level. However, local uniqueness, personality, culture, place and region, as well as interpersonal contacts on the ground are extremely important for understanding, understanding and responding to external, global forces. Much more complex is the issue of cultural and arts education in developing countries. As information sharing is now an accessible phenomenon, the demands of the globalized world on the citizens of developing countries are noticeably increasing, thus globalization is positioned as a transformative force.

M. Quieck, exploring the social and cultural dimensions of higher education transformation in Central and Eastern Europe, identifies the major global factors contributing to the transformation of higher education:

- the destruction of the role of the state in socio-economic development with its vision of higher education as a national property, which contributes to the strengthening of national consciousness;

- the functions reformulation of the state, including state-funded government-funded measures;

- the invasion of economic rationality and corporate culture into the public sector globally ${ }^{20}$.

Important factors influencing the formation of the situation in the education system in the field of culture and art are: innovative technologies, forming of student communities, new trends in higher education. Trends in the contemporary socio-cultural space require specific (changing, not fragmented) understanding and understanding of society and social issues. For example, the Government of Finland approved in 2016 the decision to introduce an innovative education system in the country by 2020, according to which schools are taught not a subject but a phenomenon. So-called Phenomenonbased learning is a multidisciplinary, constructivist form of learning whereby, unlike a subject-oriented approach, students and students learn a specific topic or concept as a whole. The new concept builds on real-world experience that reflects the interconnection of subjects and contexts. The main features of this training form are:

- providing processes in which new information lays on a particular issue, issue, or phenomenon (facilitates better assimilation of material);

- creating a deep learning environment is cognitive processes in the Phenomenon-based learning environment are typical of the subject being studied or skills that are formed in the learning process to real life situations;

${ }^{20}$ Kwiek, M. (2001). Social and Cultural Dimensions of the Transformation of Higher Education in Central and Eastern Europe. Higher Education in Europe, XXVI, 3, 399-410. DOI: 10.1080/03797720120115979. 
- positioning the student with an active form of knowledge and information (constructivist form of education).

Since the foundation of global education is based on the study of global and local ties in order to maximize global consciousness, this phenomenon, according to E. Nimchuk, should be considered in terms of dual citizenship, accompanied by certain privileges and responsibilities: "we are all citizens of a particular nation, as well as the citizens of the world who are pursuing a common goal is to understand and support the world in which we live" ${ }^{21}$, and therefore, global education is designed to provide the ability to know oneself in the context of narratives of engagement with the world and local realities ${ }^{22}$.

Glocalization involves the sublimation, adaptation, and combination of two or more processes, one of which must be local. Although, in the context of cultural and art education, glocalization can acquire hybrid features. For example, a hybrid version of higher education in Singapore incorporates original American and British models are two different systems combined for best results. However, in the context of national cultural and arts education, a meaningful approach to glocalization involves the inclusion of at least one component of the local culture, value system and practice. Undoubtedly, in the context of the globalization processes of the 21 st century global influences cannot be ignored, but positioning and localization cannot be predicted.

Modification of international templates according to national conditions instead of automatic copying is now known practice of "re-contextualization", was proposed by foreign researchers D. Dakovsky and R. Harmsen in $2015^{23}$. For example, within the framework of integrating into the higher education system of the positive experience of Western European countries, considerable attention at the present stage is paid to dual education as one of the three main forms of education in Ukraine (together with institutional and individual) since $2017^{24}$. This priority area provides:

- rethinking their own strategies for curriculum development and institutional policy in the context of the specifics of the teaching of artistic disciplines (in particular, these are special theoretical-practical courses, which

${ }^{21}$ Niemczyk, E.K. (2019). Glocal Education in Practice: Teaching, Researching, and Citizenship. In BCES Conference Books, 17. Sofia: Bulgarian Comparative Education Society, p. 14.

${ }^{22}$ Ibid.

${ }^{23}$ Dakowska, D., Harmsen, R. (2015). Laboratories of reform? The Europeanisation of higher education in Central and Eastern Europe. European Journal of Higher Education. Europeanisation, internationalization and higher education reforms in Central and Eastern Europe, 5(1), p. 6-7.

${ }^{24}$ Zakon Ukrainy Pro osvitu : pryiniatyi 05 ver. 2017 roku № 2145-VIII. (2017). Information of the Verkhovna Rada, 38-39, 380. 
provide for improving the level of training at the theoretical level, significant improvement of the practical and aimed facilitating the further employment process, etc.);

- organic integration of certain elements of international programs into the national educational process, characterized by the synthesis of fundamental, rational and artistic features in the field of culture and art, dominance of belonging to the national academic / vocational school.

The main purpose of developing contemporary curricula in the field of culture and the arts is to provide the process of providing students with a holistic, interconnected, clear and consistent experience that is relevant to their personal and professional development. In developing curricula in accordance with the concept of glocalization, it is important to: systematically update the content being taught and update it globally and locally; taking into account the individual qualities of students, their motivation, experience and more. This requirement is dictated by the fact that no system of knowledge is ideal or most acceptable in today's complex sociocultural context. Although the "global" notion implies certain standardization, global education can contribute to the development of leading teaching methods and offer a comprehensive perspective on the integrated nature of the local and global.

According to $\mathrm{K}$. Walhuther, Comparative Education can provide additional insights into understanding the value of global education, exploring opportunities, problems, and identifying best practices ${ }^{25}$. Comparative education plays an auxiliary and informative role - exploring aspects of different education systems, it takes into account the relevant (local) social contexts through which these educational systems were formed. According to $\mathrm{K}$. Wolhuter, the focus of comparative education goes beyond the focus of the education system as such, since the latter is studied in a social context and viewed as being shaped or the result of a social force (e.g., cultural, economic, political, demographic, geographic, social, etc. $)^{26}$. Accordingly, in the process of identifying and integrating best practices from one context to another, many social, cultural, environmental variables need to be considered. Sharing the opinion of some scholars (K. Mandi, K. Bickmore, R. Heiho, M. Medden, etc.), it should be noted that globalization has challenged the traditional understanding of comparative education at the level of national education systems.

${ }^{25}$ Wolhuter, C.C. (2018). Leading the Way to Impact-Making Research: The Role of Comparative International Perspectives in Research on Leadership in Education in South Africa. In C.C. Wolhuter (Ed.) Raising the Impact of Education Research in Africa. Cape Town: AOSIS (pp. 21-40).

${ }^{26}$ Ibid. 
Quality management of vocational and cultural training is positioned as a major factor providing benefits to any system, including the education system at the global level. In accordance with the specifics of the education system in the field of culture and art, in higher education institutions it is extremely important to combine the process of vocational training and teaching of general cultural disciplines. Accepted and integrated global values in the system of education in the field of culture and art of Ukraine contribute to the establishment of intercultural dialogue, the purpose of which is the evolution of aesthetic principles and artistic and creative process, as well as enhancing the manifestation of the author's individuality. However, the implementation and realization of the globalization concept in Ukraine is complicated, first of all, by the shortcomings of the administrative and legal status of educational institutions (art schools, colleges and institutions of higher education) and their affiliation with different departments (respectively, and tangible differences in financial security). At the local and regional levels, these shortcomings are manifested by the lack of the required number of cultural and art education institutions, including the absence of higher vocational education institutions for certain specialties (in particular, choreographic, fine arts, theater, etc.), which in turn creates the prerequisites for local staff shortages in this area. Complicating circumstances is the lack of motivation for the graduate to return to work in their specialty in their native town.

The implementation and popularization of the global education concept in the culture field and the arts should help to encourage research into the teaching staff and students of local and global perspectives in order to broaden and enrich the positive learning experience. In the context of the national higher education system, this concept implies giving potential graduates the opportunity to become active participants in the creative industry of postindustrial society.

\section{CONCLUSIONS}

One of the characteristic features of the education system in the culture field and art is constant changes in accordance with the transformation processes of the socio-cultural space, aimed at its modernization and compliance with the strategy of social development. As an important part of the cultural policy in modern society, the sphere of education in the field of culture and art is a complex, multidimensional and open system that contributes to the formation and the inner world development of man, the creative potential of the individual, his intellect and emotional component due to mastering a set of specific competencies; organic transfer, assimilation and 
preservation of spiritual values in the process of enculturation in order to ensure the harmonious development of society.

Essential for education in the field of culture and art in Ukraine is the implementation of the "think globally, act locally" principle, which leads to the expediency of a recoding kind of the structural modification of educational processes on the principles of glocalization. Accordingly, higher education in the field of culture and art in Ukraine in the early 2020's should meet the leading global trends, while preserving and enhancing the national character of Ukrainian culture. It should be remembered that the thoughtless borrowing of Western educational theories and practices generates a peculiar cultural divide, which causes a violation of the traditionalism of the structural and functional approach to education in the field of culture and art, which results in the loss of ethno-cultural identity.

Modern globalization processes shape the specificity and dynamics of the development of education in the field of culture and art, as they simultaneously affect the inter-ethnic relations and essential components of the structure of the Ukrainian people. Characteristic tendencies of mastering Western models (for example, dual education) and values are the manifestation of so-called "Westernization", while striving for the establishment of local self-identification and restoration of traditional values; it is a manifestation of glocalization or indigenization. Accordingly, in the context of contemporary transformation processes in the education system in the field of culture and art, it is extremely important to shift the emphasis from globalization to globalization concept and there is meaningful integration into the national educational process of the most appropriate elements of international programs. Unlike the dissemination of individual cultural elements, this concept is characterized by a comprehensive rethinking of the new, in order to preserve and enhance cultural identity in the innovative strategies context.

\section{SUMMARY}

The globalization processes influence on the education development in the field of culture and art in Ukraine has been characterized, a comparative analysis of existing world models of higher education has been made. The specifics of the national education development in the field of culture and art as a complex socio-cultural phenomenon have been identified and its specific characteristics in the conditions of glocalization have been determined. It is emphasized that education in the culture field and art in Ukraine, as a fundamental component of development, should adapt to the changes characteristic of the current stage of the world community development. The study has found that the globalization, sublimation and blending of global and 
local contexts in accordance with the specifics of national education in the field of culture and art, while preserving the differences and significant contribution of different cultural communities, promotes the intercultural dialogue establishment, the aim of which is the creative evolution principle process, as well as the promotion of the author's individuality. It is emphasized that the characteristic tendencies of mastering Western models (for example, dual education) and values are the manifestation of the so-called "Westernization", while the desire to establish local self-identification and restoration of traditional values, it is a manifestation of glocalization or indigenization. It is concluded that in the context of modern transformation processes in the education system in the field of culture and art it is extremely important to shift the emphasis from globalization to glocalization concept it is meaningful integration into the national educational process of the most appropriate elements of international programs.

\section{REFERENCES}

1. Bauman, Z. (1998). On Glocalisation: Or Globalisation for Some, Localisation for Others. Thesis Eleven, 54, 37-49.

2. Blatter, J. (2013). Glocalization. In Encyclopedia Britannica. URL: https://www.britannica.com/topic/glocalization.

3. Caniglia, G., Bellina, L., Lang, D.J., Laubichler, M. (2017). The Glocal Curriculum: A Practical Guide to Teaching and Learning in an Interconnected World. Baden-Baden: Critical Aesthetics Publishing.

4. Chinnammai, S. (2005). Effects of globalisation on education and culture. In ICDE International Conference. Madras, India: University of Madras (pp. 1-6).

5. Crossley, M. (2002). Comparative and International Education: Contemporary Challenges, Reconceptualization and New Directions for the Field. Current Issues in Comparative Education. Teachers College, Columbia University, 4(2), 81-86.

6. Dakowska, D., Harmsen, R. (2015). Laboratories of reform? The Europeanisation of higher education in Central and Eastern Europe. European Journal of Higher Education. Europeanisation, internationalization and higher education reforms in Central and Eastern Europe, 5(1), 4-17.

7. Dotsiak, I. (2017). Etnopolitychni protsesy na terytorii Halychyny v konteksti hlobalizatsii. Proceedings. Institute of Political and Ethno-National Studies National Academy of Sciences of Ukraine, 1(87), 190-198.

8. Hauser-Schäublin, B., Braukämper, U. (Hrsg.). (2002). Ethnologie der Globalisierung: Perspektiven kultureller Verflechtungen. D. Reimer, Berlin.

9. Kozhevnikov, N.N., Pashkevich, N.L. (2005). Glokalizaciya koncepcii harakternye cherty prakticheskie aspekty. Bulletin of Yakutsk State University, $3,111-115$. 
10. Kwiek, M. (2001). Social and Cultural Dimensions of the Transformation of Higher Education in Central and Eastern Europe. Higher Education in Europe, XXVI, 3, 399-410. DOI: 10.1080/03797720120115979.

11. Niemczyk, E.K. (2019). Glocal Education in Practice: Teaching, Researching, and Citizenship. In BCES Conference Books, 17. Sofia: Bulgarian Comparative Education Society (pp. 11-18).

12. Patel, F. (2017). Internationalization of HE Needs to be Replaced. University World News. URL: https://www.universityworldnews.com/ post.php?story=20170927101224475.

13. Patel, F., Lynch, H. (2013). Glocalization as an Alternative to Internationalization in Higher Education: Embedding Positive Glocal Learning Perspectives. International Journal of Teaching and Learning in Higher Education, 25(2), 223-230.

14. Rietdorf, U. (2001). Minderheiten und ihre Bedeutung für endogene Entwicklungen in Afrika: das Beispiel Tansania. Verlag Dr. Kovač, Hamburg.

15. Robertson, R. (1995). Glocalization: Time-Space and HomogeneityHeterogeneity. In M. Featherstone, S. Lash and R. Robertson (eds.) Global Modernities. London/Thousand Oaks/New Delhi, Sage (pp. 25-44).

16. Rolls, A. (2007). International perspectives on education. Bronx, NY: H.W. Wilson Co.

17. Rozenberg, N.V. (2014). Nacional'nye kul'tury kak vyzov globalizacii. News of higher educational institutions. Volga region. Humanitarian sciences, 3 (31), 111-117.

18. Wolhuter, C.C. (2018). Leading the Way to Impact-Making Research: The Role of Comparative International Perspectives in Research on Leadership in Education in South Africa. In C.C. Wolhuter (Ed.) Raising the Impact of Education Research in Africa. Cape Town: AOSIS (pp. 21-40).

19. Zakon Ukrainy Pro osvitu : pryiniatyi 05 ver. 2017 roku № 2145-VIII. (2017). Information of the Verkhovna Rada, 38-39, 380.

\section{Information about the author: Mykhailo Poplavskyi,}

Doctor of Pedagogical Sciences, Professor, Head of the PR and Journalism Department, Kyiv National University of Culture and Arts, 36, Y. Konovalets str., Kyiv, 01133, Ukraine http://orcid.org/0000-0002-8234-8-064 